\title{
The Potential Use of Microorganisms as Restorative Agents: An Update
}

\author{
Irene Soffritti ${ }^{1,2}$, Maria $D^{\prime}$ Accolti ${ }^{1,2}$, Luca Lanzoni ${ }^{2}$, Antonella Volta ${ }^{2}$, Matteo Bisi ${ }^{2}$, \\ Sante Mazzacane ${ }^{2}$ and Elisabetta Caselli $1,2, *$ D \\ 1 Section of Microbiology, Department of Medical Sciences, University of Ferrara, 44121 Ferrara, Italy \\ 2 CIAS Research Center, University of Ferrara, 44121 Ferrara, Italy \\ * Correspondence: csb@unife.it; Tel.: +39-0532-455387
}

Received: 11 June 2019; Accepted: 11 July 2019; Published: 15 July 2019

\begin{abstract}
The biodeterioration process involves every type of Cultural Heritage item, including monuments, stoneworks, frescoes, and easel paintings. The accurate study of the microbial and fungal communities dwelling on artworks, and involved in their deterioration, is essential for the adoption of optimal prevention and conservation strategies. Conventional restorative methods, that usually involve chemical and physical technologies, present some disadvantages, including short-term and unsatisfactory effects, potential damage to the treated works, human toxicity, and environmental hazards. Research in the field of restoration has paved the way for innovative biological approaches, or 'biorestoration', in which microorganisms are not only considered as an eventual danger for artworks, but rather as potential tools for restoration. The present review describes the main aspects of the biodeterioration process and highlights the most relevant biorestoration approaches: bioconsolidation, biocleaning, biological control, and new promising bio-decontaminating compounds.
\end{abstract}

Keywords: biodeterioration; bioremediation; bioconsolidation; biocleaning; bio-decontaminating compounds; Bacillus species

\section{Introduction}

Biodeterioration represents a major and significant issue in Cultural Heritage conservation and restoration, which affects historic stonework, statues, monuments, and paintings. Although the term has been in use only in the last decades, it denotes "one of the oldest problems of mankind" and literally indicates "any undesirable change in the properties of a material caused by the vital activities of organisms", as defined by H.J. Hueck in 1965 [1]. Biodeterioration phenomena, generally considered as natural recycling processes of degradation of organic and inorganic matter, occur in any type of material, such as stone, wood, metal, paper, and parchment, and therefore clearly involves artworks, consisting of one or a combination of several materials, such as monuments, statues, paintings on canvas and frescoes. In addition, deterioration process is strongly influenced by climatic and environmental parameters, e.g., extreme temperature, high humidity levels, low ventilation condition, atmospheric pollution, that cause physical and chemical damage to artworks, not only those directly exposed to the open air, encouraging and accelerating the processes of colonization of damaging microorganisms, called "Biodeteriogens" [2]. The nature of the substrate influences the colonization of different biodeteriogens and the progress of contamination on the artwork's surfaces.

Deteriorating microorganisms are classified into different nutritional groups, based on their metabolic activities [3]. Early studies reported that the deterioration of artworks mainly consisting of inorganic materials (e.g., statues, monuments, and historical buildings) is carried out especially by autotrophic microorganisms, including chemolithotrophs (sulfur-oxidizing and nitrifying bacteria) 
and photoautotrophic bacteria (algae and cyanobacteria) [2,3]. Subsequently, lysis of bacterial cells and the liberation of organic substances promote the contamination mediated by heterotrophic deteriogens, including bacterial strains and fungi (secondary colonizers) [4].

Recently, the presence of environmental pollution has been shown allowing the primary colonization of specific heterotrophic microflora on exposed stonework's surfaces, which can use pollutants as an energy source [2,4]. Therefore, there is not always subsequent colonization between autotrophs and heterotrophs, but heterotrophic microflora can be regarded as the first colonizer of stonework exposed to high pollutants levels [2,4].

The deterioration of artworks largely consisting of organic materials (such as wood, paper, papyrus, and parchments), including wooden sculptures, library materials, and paintings, is more easily performed by heterotrophic microorganisms, which enzymatically degrade and use organic compounds as their main source of carbon [3].

Artworks are frequently including several different materials, thus the susceptibility to biodeterioration phenomena is difficult to assess and is mainly influenced by their most perishable components. Among the wide array of culturally relevant items, for example, easel and mural paintings represent composite materials, containing both organic and inorganic substrates that frequently promote the colonization of a wide range of microorganisms. Their growth and metabolic activities often cause a deterioration process of the artworks, including mechanical/physical damages or aesthetic deterioration [5].

In mural paintings, first colonization is usually due to bacterial communities, including autotrophic species, which can oxidize inorganic substrates, e.g., lead in pigments [6]. Furthermore, in the presence of high level of air pollutants, in particular sulfur dioxide, sulfur-oxidizing bacteria are involved in degrading gypsum precipitates, formed on superficial painted layers [6].

Easel paintings include a mobile support (canvas, wood, paper or parchment) and a painted layer, generally showing a multi-layer structure: a preparatory layer (lime or gypsum with oil or animal glue), which is overlaid by a pictorial film, consisting in turn of several layers of colors (including organic or inorganic pigments mixed with oil or animal glue binders), and the surface is finally spread with a thin, translucent varnish, which serves as protective cover [3,7-10]. The biodeterioration processes can involve any part of painted artworks: the support, the painted side or the reverse side. Organic components of paintings (such as cellulose, starch, gums, sucrose, glucose, oils, waxes, and egg yolk) represent good nutrient sources for a wide range of heterotrophic bacteria [11]. Notably, biological attack of these materials occurs only under particular environmental conditions, such as uncontrolled levels of humidity and temperature, low ventilation and the poor state of conservation, often found in old museums and churches. These environmental conditions also promote the growth of microorganisms lying dormant on artworks, under prolonged oligotrophic conditions [3,12].

Frequent contaminants of paintings, associated with biodegradation, often belong to one of the bacterial genus Pseudomonas, Bacillus, Alcaligenes, Flavobacterium, and Staphylococcus [4,13-15]. The bacteria colonization can favor subsequent colonization by common fungi, including Aspergillus, Penicillium, Cladosporium, and Alternaria species [16,17], often associated with mechanical damages due to deep mycelia penetration and/or paint discoloration caused by their metabolic activities.

Biodeterioration processes often result from the colonization of large microbial communities and depend on the intricate interactions between different cohabiting microorganisms. Particularly relevant in the microbial deterioration of Cultural Heritage materials is the establishment and growth of a biofilm [18]. Its formation involves an initial phase of adhesion of bacteria to the surface, followed by cell division and formation of microcolonies [19]. Environmental conditions such as humidity and nutrient availability promote cell expansion and cell-to-cell communication, leading to the formation of a mature biofilm. The mature biofilm is characterized by the production of elevated amounts of extracellular polymeric substances (EPS), including polysaccharides, proteins, lipids, and pigments, that serve as protection against harmful environmental conditions and also an energy-nutrient reservoir for microorganisms [20]. 
The occurrence of EPS represents an important issue in the deterioration of artworks because their complete elimination from both surface and deep layers are difficult [21]. For example, in stoneworks, biofilms induce modifications of the natural porosity of the material, have heavy biocorrosive activity, and can also function as "pollutant-absorber" [22].

Generally, the microbial colonization of artworks is complex and strictly influenced by the different materials and environmental conditions in which artworks are located, so the full characterization of the microbial component allows to better understanding the mechanisms underlying deterioration of materials, consequently permitting to apply targeted restoration strategies. As a further difficulty, the complexity of such peculiar environments renders it even more difficult to define the whole community of resident microorganisms.

Until recently, microbiological analysis in the field of restoration has focused on the phenotypic identification of the microorganisms present on artworks. Traditional methods are based on well-known and globally endorsed microbiological techniques based on microscopy observation and/or cultural isolation, but have some important limitations. In fact, less than $10 \%$ of the bacteria present in a specific habitat can be cultured with standard laboratory methods; furthermore, even in a cultivable population, many problems can be encountered, due to media and culture conditions [18], as well to the necessity of specific novel culturing techniques [23,24].

The employment of different microscopy techniques has until now supported microbiological analysis, representing an essential tool for the observation of artistic material's structure and bacterial/fungal communities. Traditional employed techniques include optical microscopy (OM), transmission electron microscopy (TEM), and scanning electron microscopy (SEM).

To overcome these problems, since the 2000s, the introduction of DNA-based methodologies, such as Real-Time PCR and genotyping identification (NGS, WGS), has been introduced in the study of microbial contaminating populations allowing the identification of most of the present microorganisms. Such molecular analyses are in fact culture-independent methods, require smaller samples, collected directly on artifacts surfaces, and are faster than traditional identification methods [25-27]. Analysis by Real-Time PCR may also enable the discrimination of viable from dead cells, as reported in several studies [28-30].

The combined use of microscopy analysis and phenotypic/genotypic identification approaches can be usefully applied for the characterization of microbial diversity associated to biodeterioration processes in artworks, leading in the selection of the best strategy for restoration and prevention of recontamination.

The present mini-review aimed to summarize the main aspects of the biodeterioration/ biorestoration processes, with particular focus on studies of our work group and applications in Italy.

\section{Prevention and Control of Biodeterioration}

The conservation of Cultural Heritage is mainly associated with two aspects: prevention and recovery. Prevention methods (or "indirect methods") are intended to prevent and minimize the risk of microbial deterioration, inhibiting, or reducing microbial growth by controlling ambient parameters and maintaining an optimal state of cleaning and conservation. In indoor environments (museums, libraries, churches, etc.) physico-chemical parameters should be controlled and monitored, to avoid high temperature, high relative humidity, strong lighting, and poor ventilation. In addition, cleaning methods are critical in eliminating deposits of organic materials (dirt, dust), that represent a nutritive substrate for many microorganisms, and also in removing deposits of forms of biological diffusion (spores, hyphae), thus preventing microorganisms' dissemination.

In outdoor environments (such as monuments and archeological areas), the above-listed conditions cannot be efficiently controlled, and the only chance to prevent a biological attack is through routine maintenance and periodic monitoring.

Remedial methods also called "direct methods", are instead aimed at eradicating the presence of biodeteriogens organisms, and mainly involve mechanical, physical and chemical methods. Mechanical 
methods consist of the traditional removal of biological material with suitable tools. These are widely used methodologies but can lead to damage to the artwork and short-time effects. Physical methods include the use of ultraviolet (UV), gamma and X irradiation: even though they have high penetration power (gamma and X-ray) and good effectiveness on microorganism and insects respectively, their application is limited to artworks of transportable size [21,31]. In addition, UV treatment might be associated with the chemical alteration of the treated substrates. On the other hand, chemical methods foresee the use of synthetic chemicals like bactericides, fungicides, insecticides. A large part of these products shows potential unwanted side-effects: possible toxicity for the operator, risk of environmental pollution, chemical reactivity, and substrate deterioration, selection, and growth of organisms other than the original ones, and possibly more dangerous for Cultural Heritage preservation [32,33].

\section{Biorestoration Approach: Microorganisms as "Restorative Agents"}

In the search of alternative restoration methods, safe for human and environmental health, new approaches have been recently studied and applied, involving the use of beneficial microorganisms as "restorative agents". Such innovative biotechnologies are proposed both for the recovery and conservation of artworks, thanks to the enzymatic/metabolic activities of the used microorganisms (Figure 1). Microorganisms can be isolated from environment matrices, screened and selected for their ability to remove deposits of undesirable organic and inorganic substances (biocleaning activity), or for their biocalcifying capabilities, useful for consolidation of stoneworks and monuments (bioconsolidation), or as potential decontaminating agents (biological control) [34]. Due to the high level of microbial natural biodiversity, appropriate and non-pathogenic microorganisms can be selected using traditional microbiological techniques, without the need to employ genetically modified organisms (GMO) [35].

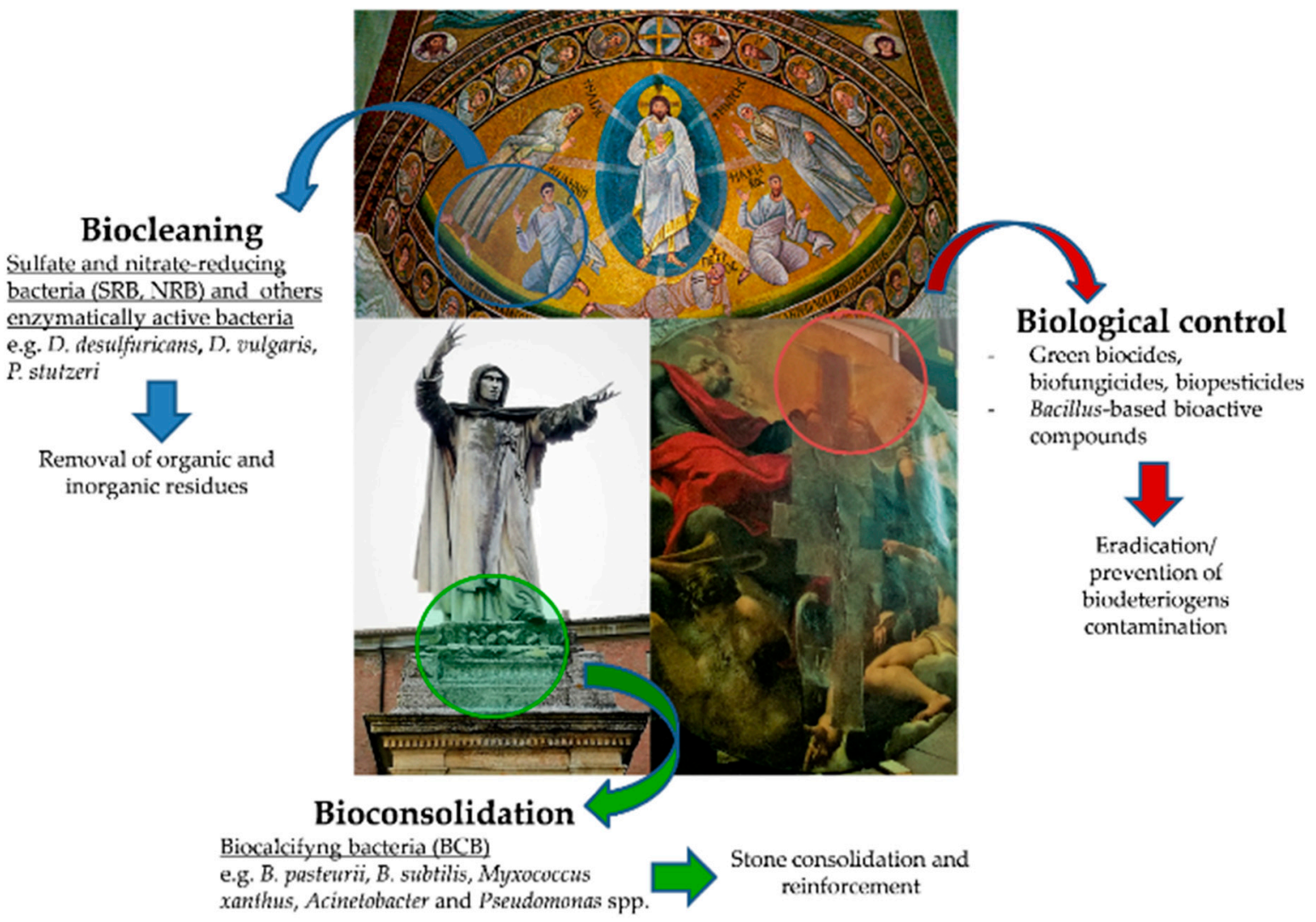

Figure 1. Biological approach: microorganisms applied for the biorestoration of artworks. 
Biorestoration technologies are currently considered effective alternatives to traditional restoration methods, as reported in several studies [34-98]. Biological approaches can be regarded as sustainable alternatives based on several aspects: (i) exploitation of natural "virtuous" microbial processes, as bacterial activity leads to natural release of carbon dioxide and water, so their employment can be considered environmentally friendly [36-38]; (ii) selection of non-pathogenic microorganisms, safe to use and without recognized hazard potential [35]; (iii) environmental safety: absence of hazardous wastes and emission, compared to chemicals methods [39]; (iv) soft intervention on artworks [35]; (v) lower or comparable cost compared to conventional methods [36].

However, further research and continue monitoring of treated artworks are needed, in order to validate over time the effectiveness of bioprocesses and verify the total safety of these methodologies [35].

\subsection{Bioremediation and Bioconsolidation}

Bioremediation is centered on the use of bacteria with different enzymatic activities and includes the use of biocalcifying bacteria (BCB), sulfate-reducing bacteria (SRB), nitrate-reducing bacteria (NRB), and hydrolytic activity due to several enzymes, such as lipases, proteases, and carbohydrases. BCB are usually used for stone consolidation and reinforcement [40], whereas SRB and NRB bacteria are employed for the reduction of sulfate and nitrate salts included in the mineral matrix, respectively. In particular, SRB reduce sulfate to gaseous hydrogen sulfide and NRB reduce nitrates to gaseous nitrogen or nitrous oxide. In addition, microbial hydrolitic activity is useful for the removal of organic deposits from artworks (mainly carbohydrates, proteinaceous and lipidic residues) [34,41,42].

Bioconsolidation has the purpose of reversing the deterioration of the calcareous matrix of stoneworks, mainly influenced by the natural weathering process and the climatic-environmental conditions to which the artworks are exposed. Metabolic activity of some bacteria produces calcite precipitation, with passive or active mechanisms. In passive carbonatogenesis, bacterial activity induces chemical changes in the micro-environment, leading to the accumulation of carbonate and bicarbonate ions and to the precipitation of solid particles. Passive precipitation is induced by several metabolic pathways of the sulphur and nitrogen cycle [43]. In active precipitation the carbonate particles are produced by ionic exchanges trough the cell membrane [34,43]. Biomineralization is a widely studied process [44-48]; several microorganisms have been proven to be effective in calcite precipitation for conservation purpose, for example, Bacillus pasteurii [49], Bacillus subtilis [40,50,51], Myxococcus xanthus [52], Acinetobacter [53], Pseudomonas, Pantoea, and Cupriavidus strains [54]. Current stone consolidation treatments are based on two strategies: the direct application of viable bacteria with biocalcifying properties (BCB), or the application of a culture medium able to induce carbonate precipitation in microorganisms present in the natural community of the treated stone [44]. Interesting results were achieved by Perito and colleagues, that proved the effectiveness of a B. subtilis cell wall fraction (BCF) in inducing calcite precipitation, testing its consolidating capability on stones both in laboratory conditions and in situ treatments [55]. A novel approach suggests the efficacy of bacterial self-inoculating treatment for consolidation of salt-damaged stones: Jroundi et al. isolated carbonatogenic bacteria from stone samples, cultured them with activating nutritive solution and re-applied the manipulate bacterial culture onto the stone samples. The incorporation of organics in calcite biominerals resulted in an organic-inorganic hybrid biomaterial, with increased bioconsolidation capacity [56].

\subsection{Biocleaning}

Biological cleaning for the restoration of artworks has been studied since the early 1990s, and nowadays this technology is efficiently used for the recovery and conservation of artworks and monuments, limiting the use of conventional chemical products. Biocleaning with different viable bacteria cultures has been used for the recovery of several signs of deterioration (black crust, mineral salts deposits, organic matter residues), proving to be more effective than chemical methods in 
removing complex and incrusted substrates, thanks to microbial highly selective and specific enzymatic activities [57].

For example, black crusts represent unaesthetic damages of stoneworks, produced by the combination of calcium sulfate dihydrate (gypsum) deposits on stone and soot particles derived from air pollution [21]. Desulfovibrio desulfuricans, an anaerobic sulfate-reducing bacteria (SRB) was the first microorganism evaluated as a cleaning agent for the reduction of gypsum and black crust in marble. These earliest results were obtained using the immersion system of samples in the bacterial growth medium $[58,59]$. Subsequent research projects focused on confirming the effectiveness of the bacterial treatments, on the optimization of procedures, time and number of applications needed, and on finding the best delivery systems [60]. Subsequently, such biotechnique was improved by using specific strains of Desulfovibrio spp. capable of acting also out of water [61], and aerotolerant strains of Desulfovibrio vulgaris subsp. vulgaris (ATCC 29579), together with Carbogel as the delivery system of the treatment [62]. Compared to a traditional chemical-based treatment (ammonium carbonate-EDTA mixture), the biological procedure showed homogeneous results in the removal of the surface deposits; in addition, the treatment preserved the historical layers below the crust (patina noble) and did not form undesirable secondary products [63]. After the first pioneering works, D. desulfuricans and D. vulgaris have been effectively used in bioremediation of various historic stoneworks and monuments, including the Cathedral of Milan [63], two sculptures of J. Eberle used to decorate the Buonconsiglio Castle in Trento [64], a section of the marble base of Pietà Rondanini in Sforzesco Castle in Milan [65], Lazzerini's sculpture "Allegoria della Morte" in Florence [66], and historical columns in Failaka Island [67].

As for sulfates, nitrate salts deposits are often related to stoneworks deterioration. The formation of salt efflorescence represents also one of the main causes of deterioration of indoor wall paintings, leading to the generation of microcracks in artwork surfaces. Nitrate efflorescence can also be the result of biological processes, due to the natural aging of painting substances or residuals of restoration products [68]. In early bioremediation studies, nitrate-reducing bacteria (NRB) were applied for the reduction of nitrate salts embedded in the mineral matrix of stoneworks. Ranalli et al. were the first to ascertain the nitrate-reducing activity of a strain of Pseudomonas stutzeri on damaged stone [69]. Bioremediation with P. stutzeri was tested not only on outdoor monuments [70], but also for the biocleaning of salt efflorescence from wall paintings, introducing an innovative delivery system based on agar carrier [71]. Besides the most investigated species of nitrate-reducing bacteria, a recent innovative study suggests the feasibility of using extremophilic bacteria, in particular Halomonas campaniensis spp., for biocleaning of nitrate crusts on stone surfaces, demonstrating also the safety of use of this kind of biological approaches [72].

Often, the crusts have a multicomponent composition, including sulfate deposits, nitrate salts, and other compounds such as carbonates, apatite, and proteins traces. These complex matrixes have been treated by combined bioremediation strategies: SRB-Carbogel application coupled with mechanical pre-intervention on crust [73] or chemical pretreatment with a nonionic detergent [74]; mixture of SRB (D. vulgaris ATCC 29579) and NRB (Pseudomonas pseudoalcaligenes KF707) in a multilayer biosystem [75]; SRB added with bacterial strains able to degrade different protein matrices [76].

As mentioned, also the presence of organic residues derived from previous or inadequate restorations can favor microbial and fungal colonization, accelerating biodeterioration phenomena.

Biorestoration treatments can also be performed for removing residues of organic substances, for example casein, egg yolk, oil, and animal fat, which are difficult to remove with other techniques. Pseudomonas stutzeri was successfully used for the removal of organic matter from wall paintings [36,77-81], including animal glue residues due to the "strappo" technique, applied between painted frescoes and the adhering gauze for detaching frescoes from walls during the Second World War. Recently, promising results were obtained by using an innovative agar-gauze biogel system, activated with viable P.stutzeri cells. In situ tests showed the need of short application times, together with easy applicability and good effectiveness, thus supporting the method as an alternative and more versatile approach to the conventional chemical-mechanical based techniques [37]. The success of 
biotreatments with viable microorganisms can be attributed to the high versatility of the bacteria, and their wide range of enzymatic activities, both constitutive and inducible. Their use results more effective compared to the treatment with enzymes such as proteases and collagenases, and in general the use of individual enzymes is highly specific and limited, resulting also less convenient, compared to the cost of bacterial biorestoration $[36,37]$.

Biocleaning approach has recently been evaluated also for the removal of graffiti paint, a very common cause of disfigurement of monuments, buildings and other urban structures. Sanmartin et al. investigate an efficient biocleaning protocol for in situ application, reducing time of treatment and using a specific culture medium for the adaptation of bacteria to target substrate [82-84].

\subsection{Biological Methods for the Control of Microbial Contamination}

Biorestoration technologies described herein (stone bioconsolidation, biocleaning of inorganic and organic deposits) are nowadays widely applied to Cultural Heritage. They are considered useful alternatives to traditional and more invasive approaches, such as chemical or mechanical methods, and proved to be effective in solving various types of damage, with the utilization of different strains of viable bacteria. So far, bacteria have been mainly harnessed for their ability to metabolize or produce inorganic compounds of restorative interest, but relatively few studies have been carried out to evaluate their use as potential decontaminating agents on artworks. Biological methods currently experimented include both the application of parasitic and antagonistic species of biodeteriogens and products of secondary metabolism of microorganisms and/or plants, defined as "green biocides". Biological control, already widely used in agriculture, is based on the use of parasitic or antagonistic organisms of the biodeteriogen ones. The utilization of biopesticides, for example, is showing increasing interest in pest control, due to target specificity, low toxicity to nontarget organisms, human being included, and low environmental impact [85-87]. However, further studies are needed for the application in the restoration field.

Biocide treatments represent traditional and widely used methods for artwork restoration. Since many chemical compounds have shown toxicity for human and animal health, as they may accumulate in animal tissue, innovative researches are aimed at developing innovative "green biocides", mainly derived from the secondary metabolism of microorganisms and/or plants.

Bacillus species are an object of great interest because they can produce a great range of secondary metabolites with biological activity [88]; for example, some strains of Bacillus subtilis and Bacillus amyloliquefaciens are able to produce antifungal peptides [89-91]. Bioactive peptides include antifungal peptides, antifungal lipopeptides, and antimicrobial polypeptides. Microbial lipopeptide compounds are naturally produced as defense mechanisms to stress situation, like sporulation [92]. Silva and colleagues tested several Bacillus spp. strains against Cladosporium spp., Penicillium spp., Fusarium oxysporum and Aspergillus niger isolated from biodegraded mural paintings, reporting that Bacillus strains produce biosurfactant lipopeptides that inhibit fungal growth [92]. The same research team has evaluated also the toxicological risks of these Bacillus-derived bioactive compounds, reporting specific antifungal activity and the absence of toxic effects against other living organisms [93]. In recent research, the combined use of antifungal screening and molecular analysis has been suggested as a possible methodology for quick identification and subsequent efficient selection of lipopeptides-producer strains [94]. Other researches focused on the potential use of other bacterial, fungal and plant derivates as biocides agents [95-97].

Recently, the potential use of a Bacillus-based biocompound to prevent the biodeterioration of artworks has also been reported in a paper analyzing the microbial population contaminating in a 17th century easel painting, attributed to the painter Carlo Bononi: having isolated the microbial species contaminating the painting, they were used as a target microbes in in vitro assays to test the decontaminating activity of a biocompound containing spores of specific probiotic Bacillus strains (namely B. subtilis, B. pumilus, B. megaterium) [17]. Bacillus genus includes sporogenic, ubiquitous bacteria, recognized as safe for human health except for B.anthracis and B.cereus $[99,100]$. 
The antimicrobial activity of species belonging to the Bacillus genus has been reported in several studies, showing the capability of Bacillus strains to counteract different types of pathogenic bacteria [101-103]. On another hand, Bacillus spores have a long history of safe use in humans and are successfully utilized as anti-fungals in agriculture [104], and as infection-prevention agents in aquaculture and zootechnics [105-108]. Notably, Bacillus spores are resistant to many physical-chemical factors, thus rendering them particularly suitable for addition to different types of solutions. When applied on surfaces, spore germination occurs originating the vegetative bacteria, which are responsible for cleaning action. Previous studies, performed by our group on hard surfaces (prevalently in the hospital environment) showed the antimicrobial activity of such Bacillus strains against several bacteria and mycetes, suggesting a potential wider use [109-115]. Bacillus action appears mainly based on enzymatic activity and competitive antagonisms, although the production of bacteriocins and other bioactive compounds might also be involved. In the field of Cultural Heritage conservation, cleaning products consisting in detergent solutions added with Bacillus spores, have been proposed for the treatment of the biological patina on stone materials, showing no interaction with stone samples (absence of decohesion, discoloration, fractures or porosity increases), and have been thus suggested as potential biological agents useful for biorestoration [98]. Accordingly with the already reported uses of Bacillus-based biocompounds, the results obtained by us on the individual bacterial/fungal species isolated from an ancient easel painting showed that selected Bacillus species can inhibit the development of all the contaminant isolates (bacteria and mycetes), confirming previous works and suggesting a potential use of such Bacillus strains for the decontamination of artworks surfaces and the prevention of their further colonization.

The studies analyzing the use and applicability of biological systems for biorestoration are summarized in Table 1. 
Table 1. Biorestoration compounds and methods reported in the scientific literature.

\begin{tabular}{|c|c|c|c|c|c|}
\hline Year & Microorganism/s & Artwork & Application & Mechanism/Findings & References $\left[n^{\circ}\right]$ \\
\hline 1988 & D. desulfuricans ${ }^{1}$ & Stonework & Immersion & $\begin{array}{l}\text { Removal of sulphates from marble } \\
\text { (in vitro tests) }\end{array}$ & [59] \\
\hline 1992 & D. desulfuricans & Stonework & Immersion & $\begin{array}{l}\text { Removal of sulphates from marble } \\
\text { (in vitro tests) }\end{array}$ & [58] \\
\hline 1996 & P. stutzeri ${ }^{2}$ & Stonework & Sepiolite as delivery system & $\begin{array}{c}\text { Removal of nitrates from } \\
\text { brickwords/calcareous stones } \\
\text { (in vitro tests) }\end{array}$ & [69] \\
\hline 1997 & Desulfovibrio spp. & Stonework & Sepiolite as delivery system & $\begin{array}{l}\text { Removal of sulphates from marble } \\
\text { (in vitro tests) }\end{array}$ & [61] \\
\hline 2001 & B. pasteurii ${ }^{3}$ & Stonework & $\begin{array}{l}\text { Cells immobilized in } \\
\text { polyurethane foam }\end{array}$ & $\begin{array}{c}\text { Bioconsolidation of concrete } \\
\text { (in vitro tests) }\end{array}$ & [49] \\
\hline 2003 & M. xanthus ${ }^{4}$ & Stonework & Immersion & $\begin{array}{l}\text { Bioconsolidation of ornamental } \\
\text { limestone (in vitro tests) }\end{array}$ & [52] \\
\hline 2005 & D. vulgaris subsp. vulgaris & Stonework & Carbogel carrier & $\begin{array}{l}\text { Removal of black crusts from } \\
\text { marble sculpture }\end{array}$ & [65] \\
\hline 2005 & P. stutzeri & Fresco & $\begin{array}{l}\text { Application with cotton wool layer } \\
\text { (enzymes added) }\end{array}$ & Removal of animal glue from frescoes & [36] \\
\hline 2006 & D. vulgaris subsp. vulgaris & Stonework & $\begin{array}{l}\text { Sepiolite/ Hydrobiogel-97/carbogel } \\
\text { carrier }\end{array}$ & $\begin{array}{l}\text { Removal of black crusts from } \\
\text { marble surfaces }\end{array}$ & [62] \\
\hline 2007 & D. vulgaris subsp. vulgaris & Stonework & Carbogel carrier & $\begin{array}{c}\text { Removal of black crusts from } \\
\text { marble surfaces }\end{array}$ & [63] \\
\hline 2008 & $\begin{array}{c}\text { D. vulgaris subsp. vulgaris, } \\
\text { P. pseudoalcaligenes }{ }^{5}, \text { P. stutzeri }\end{array}$ & Stonework & Carbogel/Mortar and alginate beads & $\begin{array}{l}\text { Removal of nitrates and sulphates } \\
\text { from sandstone walls }\end{array}$ & [70] \\
\hline 2010 & D. vulgaris subsp. vulgaris & Stonework & $\begin{array}{l}\text { Carbogel (mechanical } \\
\text { treatment added) }\end{array}$ & $\begin{array}{l}\text { Removal of black crusts from colored } \\
\text { lithotypes }\end{array}$ & [73] \\
\hline 2010 & D. vulgaris subsp. vulgaris & Stonework & $\begin{array}{l}\text { Carbogel carrier (biocide } \\
\text { treatment added) }\end{array}$ & $\begin{array}{c}\text { Removal of black crusts from } \\
\text { limestone sculpture }\end{array}$ & [64] \\
\hline 2011 & $\begin{array}{l}\text { D. vulgaris subsp. vulgaris } \\
\text { P. pseudoalcaligenes }\end{array}$ & Stonework & Carbogel with multilayer biosystem & $\begin{array}{l}\text { Removal of nitrates and sulphates } \\
\text { from sandstone walls }\end{array}$ & [75] \\
\hline 2012 & P. stutzeri & Fresco & Application with cotton wool layer & Removal of animal glue from frescoes & [79] \\
\hline 2013 & P. stutzeri & Wall painting & Agar carrier & $\begin{array}{l}\text { Removal of animal glue and nitrates } \\
\text { from wall paintings }\end{array}$ & {$[71,80]$} \\
\hline 2013 & Pseudomonas, Pantoea, Cupriavidus & Stonework & Immersion & $\begin{array}{l}\text { Bioconsolidation of stone by } \\
\text { resident-carbonatogenic } \\
\text { microorganisms (in vitro tests) }\end{array}$ & [54] \\
\hline
\end{tabular}


Table 1. Cont.

\begin{tabular}{|c|c|c|c|c|c|}
\hline Year & Microorganism/s & Artwork & Application & Mechanism/Findings & References $\left[n^{\circ}\right]$ \\
\hline 2013 & D. vulgaris subsp. vulgaris & Stonework & Carbogel carrier & $\begin{array}{c}\text { Removal of black crusts from } \\
\text { marble surfaces }\end{array}$ & [66] \\
\hline 2013 & B. gladioli pv. agaricicola 6 & Stonework & $\begin{array}{l}\text { In vitro tests (only bacterial } \\
\text { metabolites) }\end{array}$ & $\begin{array}{l}\text { Decontaminating activity against } \\
\text { biodeteriogenic bacteria/fungi } \\
\text { (in vitro tests) }\end{array}$ & [95] \\
\hline 2013 & D. vulgaris subsp. vulgaris & Stonework & $\begin{array}{l}\text { Arbocel (nonionic detergent treatment } \\
\text { added) }\end{array}$ & $\begin{array}{c}\text { Removal of black crusts from } \\
\text { marble surfaces }\end{array}$ & [74] \\
\hline 2014 & $\begin{array}{c}\text { C. cellulans }{ }^{7}, \text { S. maltophilia }{ }^{8} \text {, } \\
\text { P. koreensis }{ }^{9}\end{array}$ & Wall painting & Laponite micro-packs & $\begin{array}{l}\text { Biocleaning of organic/inorganic } \\
\text { residues from wall painting }\end{array}$ & [76] \\
\hline 2015 & Bacillus spp. & Wall painting & Immersion (only bacterial metabolites) & $\begin{array}{c}\text { Decontaminating activity against } \\
\text { biodeteriogenic fungi (in vitro tests) }\end{array}$ & [92] \\
\hline 2016 & Bacillus spp. & Stonework & Spraying & $\begin{array}{l}\text { Biocleaning of biological patina from } \\
\text { historical bricks (in vitro tests) }\end{array}$ & [115] \\
\hline 2016 & B. subtilis 10 & Stonework & Spraying & $\begin{array}{l}\text { Bioconsolidation of historical } \\
\text { limestone (in vitro tests) }\end{array}$ & [50] \\
\hline 2017 & $\begin{array}{l}\text { Indigenous carbonatogenic } \\
\text { bacteria }\end{array}$ & Stonework & Self-inoculation of stone's bacteria & $\begin{array}{l}\text { Bioconsolidation of stone by } \\
\text { self-inoculation of resident- } \\
\text { carbonatogenic microorganisms }\end{array}$ & [56] \\
\hline 2018 & Bacillus spp. & Easel painting & In vitro tests & $\begin{array}{l}\text { Decontaminating activity against } \\
\text { biodeteriogenic bacteria/fungi } \\
\text { (in vitro tests) }\end{array}$ & [17] \\
\hline 2018 & D. vulvaris & Stonework & Hydrobiogel-97 & $\begin{array}{c}\text { Removal of black crust from } \\
\text { stone surfaces }\end{array}$ & [67] \\
\hline 2018 & P. stutzeri & Fresco & Brush and cotton layers & Removal of animal glue from frescoes & [81] \\
\hline 2019 & P. stutzeri & Wall painting & Agar-gauze biogel & $\begin{array}{l}\text { Removal of organic residues from } \\
\text { wall paintings }\end{array}$ & [37] \\
\hline 2019 & H.campaniensis ${ }^{11}$ & Stonework & $\begin{array}{l}\text { Bacterial layer spread with spatula } \\
\text { and agar disc }\end{array}$ & $\begin{array}{c}\text { Removal of nitrate crusts from } \\
\text { stone artwork }\end{array}$ & [72] \\
\hline 2019 & $\begin{array}{l}\text { P. stutzeri, A. aerogenes }{ }^{12} \\
\text { Comamonas spp. }\end{array}$ & Stonework & $\begin{array}{l}\text { Application with cotton wool } \\
\text { layer/agar carrier }\end{array}$ & $\begin{array}{l}\text { Biocleaning of graffiti paints from } \\
\text { granite and concrete surfaces } \\
\text { (in vitro tests) }\end{array}$ & [84] \\
\hline
\end{tabular}

${ }^{1}$ Desulfovibrio desulfuricans; ${ }^{2}$ Pseudomonas stutzeri; ${ }^{3}$ Bacillus pasteurii; ${ }^{4}$ Myxococcus xanthus; ${ }^{5}$ Pseudomonas pseudoalcaligenes; ${ }^{6}$ Burkholderia gladioli pv. agaricicola $;{ }^{7}$ Cellulosimicrobium cellulans;

${ }^{8}$ Stenotrophomonas maltophilia; ${ }^{9}$ Pseudomonas koreensis; ${ }^{10}$ Bacillus subtilis; ${ }^{11}$ Halomonas campaniensis; ${ }^{12}$ Aerobacter aerogenes. 
However, studies are needed to ascertain the absence of any possible interaction between the Bacillus strains with painting substrate. Furthermore, it is important to assess the persistence in time of the treatment on surfaces, particularly in those exposed on environmental deteriorating agents; the optimization of methods and number of applications required; the evaluation of costs, in comparison with chemical compounds or other common treatments. If such studies yield positive results, Bacillus biocompounds might be used to fight and prevent biodeterioration of painting and artwork in general.

\section{Concluding Remarks}

In conclusion, biological technologies represent a promising approach for Cultural Heritage restoration, providing eco-sustainable alternatives, relatively easy to set-up and improve, and harmless for human and environmental health. More researches should evaluate if biorestoration technologies are really soft and safer, even when the cleaned artwork is subjected over time to different environmental conditions (for example indoor or outdoor relocation). Recent researches are focusing on confirming the effectiveness of biological system, the improving of methods and time of application and the selection of the most efficient delivery system for each treatment. Promising results have been achieved, for example, with an advanced delivery system (agar-gauze gel activated with bacteria) on wall paintings [37]. In addition, the potential use of specific microorganisms belonging to the Bacillus genus has been suggested as a decontaminating approach against painting's biodeteriogens [17]. Future investigation is needed, in order to monitor the safety and the effectiveness of this approach, with short-term and long-term surveillance. Rapid and routinely analyses (such as monitoring of ATP content and dehydrogenase activity) [36] are essential to monitor the biological activity and avoid undesirable effects of biorestoration processes. The confirmation of the safety of these new approaches will further favor their diffusion and wide-range application, leading to the definition of standardized protocols and cost-to-benefit evaluations.

In parallel, studies focusing on the complete understanding of the contaminating microbiota composition and on the metabolic potential of the microbial community involved in biodeterioration phenomena shall open new potential perspectives for the use of counteracting "good" microbes. To this purpose, next generation sequencing (NGS) methodologies are being adopted recently in the field of Cultural Heritage, as reviewed by Perito et al. [116]. In fact, the development/implementation of molecular techniques, such as $16 \mathrm{~S}$ ribosomal NGS molecular analysis, to obtain the whole microbiota pathway dwelling on artworks surfaces, such as painting, easel, or stonework, would also allow the real-time monitoring of composition and modification of the microbiota, before and after bio cleaning interventions. It would be useful to understand not only the taxon composition of microbial communities on artworks, but also how those populations interact with each other and with different artworks materials. Metagenomics approaches, based on NGS or, even better, the recently developed whole genome sequencing (WGS) techniques, require non-invasive sampling, and could be usefully combined with culture-dependent techniques to investigate the biodiversity on artworks objects and the mechanisms of biodeterioration processes, thus allowing to evaluate the most effective strategies for Cultural Heritage conservation.

Author Contributions: Conceptualization, E.C., I.S., S.M.; methodology, E.C., I.S., M.D.A., L.L., A.V., M.B.; validation, E.C., I.S., S.M.; formal analysis, E.C., I.S., M.D.A., S.M.; investigation, I.S., M.D.A., L.L, A.V., M.B.; data curation, E.C., I.S.; writing — original draft preparation, I.S., E.C.; writing—review and editing, E.C., S.M.; supervision, E.C., S.M.

Funding: This research received no external funding.

Acknowledgments: We thank Consorzio Futuro in Ricerca (CFR, Ferrara) for the administrative support.

Conflicts of Interest: The authors declare no conflict of interest. 


\section{References}

1. Hueck, H.J. The biodeterioration of materials-An appraisal (Reprinted). Int. Biodeterior. Biodegrad. 2001, 48, 5-11. [CrossRef]

2. Ranalli, G.; Zanardini, E.; Sorlini, C. Biodeterioration-Including Cultural Heritage. In Encyclopedia of Microbiology, 3rd ed.; Schaechter, M., Ed.; Academic Press: Oxford, UK, 2009; pp. 191-205.

3. Caneva, G.; Nugari, M.P.; Salvadori, O. Environmental factors in biodeterioration. In Biology in the Conservation of Works of Art; Caneva, G., Nugari, M.P., Salvadori, O., Eds.; ICCROM: Rome, Italy, 1991; pp. 3-24.

4. Nuhoglu, Y.; Oguz, E.; Uslu, H.; Ozbek, A.; Ipekoglu, B.; Ocak, I.; Hasenekoglu, I. The accelerating effects of the microorganisms on biodeterioration of stone monuments under air pollution and continental-cold climatic conditions in Erzurum, Turkey. Sci. Total Environ. 2006, 364, 272-283. [CrossRef] [PubMed]

5. Allsopp, D.; Seal, K.J.; Gaylarde, C.C. Introduction to Biodeterioration, 2nd ed.; Cambridge University Press: Cambridge, UK, 2004.

6. Ciferri, O. Microbial degradation of paintings. Appl. Environ. Microbiol. 1999, 65, 879-885. [PubMed]

7. Leonardi, R. Nuclear physics and painting: Sub-topic of the wide and fascinating field of science and art. Nucl. Phys. A 2005, 752, 659c-674c. [CrossRef]

8. Stulik, D. Paint. The Science of Paintings; Taft, W.S.J., Mayer, J.W., Eds.; Springer: New York, NY, USA, 2000; pp. 12-25.

9. Taft, W.S.; Mayer, J.W. The Structure and Analysis of Paintings. In The Science of Paintings; Taft, W.S.J., Mayer, J.W., Eds.; Springer: New York, NY, USA, 2000; pp. 1-11.

10. Matteini, M.; Mazzeo, R. Structure of panel and canvas paintings. In Scientific Examination for the Investigation of Paintings, a Handbook for Conservator-Restorers; Pinna, D., Galeotti, M., Mazzeo, R., Eds.; Centro Di: Firenze, Italy, 2009; pp. 11-20.

11. Strzelczyk, A.B. Paintings and sculptures. Econ. Microbiol. 1981, 6, 203-234.

12. Pinna, D.; Salvadori, O. Processes of biodeterioration: General mechanisms. In Plant Biology for Cultural Heritage: Biodeterioration and Conservation; Caneva, G., Nugari, M.P., Salvadori, O., Eds.; The Getty Conservation Institute: Los Angeles, CA, USA, 2008; pp. 15-34.

13. Capodicasa, S.; Fedi, S.; Porcelli, A.M.; Zannoni, D. The microbial community dwelling on a biodeteriorated 16th century painting. Int. Biodeterior. Biodegrad. 2010, 64, 727-733. [CrossRef]

14. Lopez-Miras, M.D.; Martin-Sanchez, I.; Yebra-Rodriguez, A.; Romero-Noguera, J.; Bolivar-Galiano, F.; Ettenauer, J.; Sterflinger, K.; Pinar, G. Contribution of the Microbial Communities Detected on an Oil Painting on Canvas to Its Biodeterioration. PLoS ONE 2013, 8, e80198. [CrossRef] [PubMed]

15. Pavic, A.; Ilic-Tomic, T.; Pacevski, A.; Nedeljkovic, T.; Vasiljevic, B.; Moric, I. Diversity and biodeteriorative potential of bacterial isolates from deteriorated modern combined-technique canvas painting. Int. Biodeterior. Biodegrad. 2015, 97, 40-50. [CrossRef]

16. Gorbushina, A.A.; Heyrman, J.; Dornieden, T.; Gonzalez-Delvalle, M.; Krumbein, W.E.; Laiz, L.; Petersen, K.; Saiz-Jimenez, C.; Swings, J. Bacterial and fungal diversity and biodeterioration problems in mural painting environments of St. Martins church (Greene-Kreiensen, Germany). Int. Biodeterior. Biodegrad. 2004, 53, 13-24. [CrossRef]

17. Caselli, E.; Pancaldi, S.; Baldisserotto, C.; Petrucci, F.; Impallaria, A.; Volpe, L.; D'Accolti, M.; Soffritti, I.; Coccagna, M.; Sassu, G.; et al. Characterization of biodegradation in a 17th century easel painting and potential for a biological approach. PLoS ONE 2018, 13, e0207630. [CrossRef] [PubMed]

18. McNamara, C.J.; Mitchell, R. Microbial deterioration of historic stone. Front. Ecol. Environ. 2005, 3, 445-451. [CrossRef]

19. Costerton, J.W.; Stewart, P.S.; Greenberg, E.P. Bacterial biofilms: A common cause of persistent infections. Science 1999, 284, 1318-1322. [CrossRef] [PubMed]

20. Costerton, J.W.; Lewandowski, Z.; Caldwell, D.E.; Korber, D.R.; Lappinscott, H.M. Microbial Biofilms. Annu. Rev. Microbiol. 1995, 49, 711-745. [CrossRef] [PubMed]

21. Warscheid, T.; Braams, J. Biodeterioration of stone: A review. Int. Biodeterior. Biodegrad. 2000, 46, 343-368. [CrossRef]

22. Warscheid, T.; Oelting, M.; Krumbein, W.E. Physicochemical Aspects of Biodeterioration Processes on Rocks with Special Regard to Organic Pollutants. Int. Biodeterior. 1991, 28, 37-48. [CrossRef] 
23. Saiz-Jimenez, C.; Laiz, L. Occurrence of halotolerant/halophilic bacterial communities in deteriorated monuments. Int. Biodeterior. Biodegrad. 2000, 46, 319-326. [CrossRef]

24. McNamara, C.J.; Perry, T.D.; Zinn, M.; Breuker, M.; Mitchell, R. Microbial processes in the deterioration of Mayan archaeological buildings in southern Mexico. In Art, Biology, and Conservation: Biodeterioration of Works of Art; Koestler, R.J., Koestler, V., Charola, A.E., Nieto-Fernandez, F.E., Eds.; The Metropolitan Museum of Art: New York, NY, USA, 2003; pp. 248-265.

25. Schabereiter-Gurtner, C.; Pinar, G.; Lubitz, W.; Rolleke, S. An advanced molecular strategy to identify bacterial communities on art objects. J. Microbiol. Methods 2001, 45, 77-87. [CrossRef]

26. Schabereiter-Gurtner, C.; Saiz-Jimenez, C.; Pinar, G.; Lubitz, W.; Rolleke, S. Phylogenetic diversity of bacteria associated with Paleolithic paintings and surrounding rock walls in two Spanish caves (Llonin and La Garma). FEMS Microbiol. Ecol. 2004, 47, 235-247. [CrossRef]

27. Milanesi, C.; Baldi, F.; Vignani, R.; Ciampolini, F.; Faleri, C.; Cresti, M. Fungal deterioration of medieval wall fresco determined by analysing small fragments containing copper. Int. Biodeterior. Biodegrad. 2006, 57, 7-13. [CrossRef]

28. Wang, S.; Levin, R.E. Discrimination of viable Vibrio vulnificus cells from dead cells in real-time PCR. J. Microbiol. Methods 2006, 64, 1-8. [CrossRef]

29. Wang, L.; Li, Y.; Mustapha, A. Detection of viable Escherichia coli O157:H7 by ethidium monoazide real-time PCR. J. Appl. Microbiol. 2009, 107, 1719-1728. [CrossRef] [PubMed]

30. Wang, L.X.; Mustapha, A. EMA-Real-Time PCR as a Reliable Method for Detection of Viable Salmonella in Chicken and Eggs. J. Food Sci. 2010, 75, M134-M139. [CrossRef] [PubMed]

31. Salvadori, O. The control of biodeterioration. Coalition 2003, 6, 16-20.

32. Cappitelli, F.; Sorlini, C. From papyrus to compact disc: The microbial deterioration of documentary heritage. Crit. Rev. Microbiol. 2005, 31, 1-10. [CrossRef] [PubMed]

33. Kumar, R.; Kumar, A.V. Biodeterioration of Stone in Tropical Environments: An Overview; The Getty Conservation Institute: Los Angeles, CA, USA, 1999.

34. Fernandes, P. Applied microbiology and biotechnology in the conservation of stone cultural heritage materials. Appl. Microbiol. Biotechnol. 2006, 73, 291-296. [CrossRef] [PubMed]

35. Bosch-Roig, P.; Ranalli, G. The safety of biocleaning technologies for cultural heritage. Front. Microbiol. 2014, 5, 155. [CrossRef] [PubMed]

36. Ranalli, G.; Alfano, G.; Belli, C.; Lustrato, G.; Colombini, M.P.; Bonaduce, I.; Zanardini, E.; Abbruscato, P.; Cappitelli, F.; Sorlini, C. Biotechnology applied to cultural heritage: Biorestoration of frescoes using viable bacterial cells and enzymes. J. Appl. Microbiol. 2005, 98, 73-83. [CrossRef] [PubMed]

37. Ranalli, G.; Zanardini, E.; Rampazzi, L.; Corti, C.; Andreotti, A.; Colombini, M.P.; Bosch-Roig, P.; Lustrato, G.; Giantomassi, C.; Zari, D.; et al. Onsite advanced biocleaning system on historical wall paintings using new agar-gauze bacteria gel. J. Appl. Microbiol. 2019, 126, 1785-1796. [CrossRef]

38. Junier, P.; Joseph, E. Microbial biotechnology approaches to mitigating the deterioration of construction and heritage materials. Microb. Biotechnol. 2017, 10, 1145-1148. [CrossRef]

39. Kohli, R. Chapter 15-Application of Microbial Cleaning Technology for Removal of Surface Contamination. In Developments in Surface Contamination and Cleaning: Applications of Cleaning Techniques, 1st ed.; Kohli, R., Mittal, K.L., Eds.; Elsevier: Amsterdam, The Netherlands, 2019; pp. 591-617.

40. Tiano, P.; Biagiotti, L.; Mastromei, G. Bacterial bio-mediated calcite precipitation for monumental stones conservation: Methods of evaluation. J. Microbiol. Methods 1999, 36, 139-145. [CrossRef]

41. Saiz-Jimenez, C. Biodeterioration vs. biodegradation: The role of microorganisms in the removal of pollutants deposited on historic buildings. Int. Biodeterior. Biodegrad. 1997, 24, 225-232. [CrossRef]

42. Wolbers, R. Cleaning Painted Surfaces: Aqueous Methods; Archetype Publications: London, UK, 2000.

43. Castanier, S.; Le Metayer-Levrel, G.; Perthuisot, J.P. Ca-carbonates precipitation and limestone genesis-the microbiogeologist point of view. Sediment. Geol. 1999, 126, 9-23. [CrossRef]

44. Jroundi, F.; Gomez-Suaga, P.; Jimenez-Lopez, C.; Gonzalez-Munoz, M.T.; Fernandez-Vivas, M.A. Stone-isolated carbonatogenic bacteria as inoculants in bioconsolidation treatments for historical limestone. Sci. Total Environ. 2012, 425, 89-98. [CrossRef] [PubMed]

45. Rodriguez-Navarro, C.; Jroundi, F.; Schiro, M.; Ruiz-Agudo, E.; Gonzalez-Munoz, M.T. Influence of Substrate Mineralogy on Bacterial Mineralization of Calcium Carbonate: Implications for Stone Conservation. Appl. Environ. Microb. 2012, 78, 4017-4029. [CrossRef] [PubMed] 
46. Santhosh, K.; Ramakrishnan, S.K.; Ramakrishnan, V.; Bang, S.S. Remediation of concrete using microorganisms. ACI Mater. J. 2001, 98, 3-9.

47. De Muynck, W.; De Belie, N.; Verstraete, W. Microbial carbonate precipitation in construction materials: A review. Ecol. Eng. 2010, 36, 118-136. [CrossRef]

48. Reddy, M.S. Biomineralization of calcium carbonates and their engineered applications: A review. Front. Microbiol. 2013, 4, 314.

49. Bang, S.S.; Galinat, J.K.; Ramakrishnan, V. Calcite precipitation induced by polyurethane-immobilized Bacillus pasteurii. Enzym. Microb. Technol. 2001, 28, 404-409. [CrossRef]

50. Micallef, R.; Vella, D.; Sinagra, E.; Zammit, G. Biocalcifying Bacillus subtilis cells effectively consolidate deteriorated Globigerina limestone. J. Ind. Microbiol. Biotechnol. 2016, 43, 941-952. [CrossRef]

51. Perito, B.; Mastromei, G. Conservation of monumental stones by bacterial biomineralization. Microbiol. Today 2003, 30, 113-114.

52. Rodriguez-Navarro, C.; Rodriguez-Gallego, M.; Ben Chekroun, K.; Gonzalez-Munoz, M.T. Conservation of ornamental stone by Myxococcus xanthus-induced carbonate biomineralization. Appl. Environ. Microb. 2003, 69, 2182-2193. [CrossRef] [PubMed]

53. Jimenez-Lopez, C.; Rodriguez-Navarro, C.; Pinar, G.; Carrillo-Rosua, F.J.; Rodriguez-Gallego, M.; Gonzalez-Munoz, M.T. Consolidation of degraded ornamental porous limestone stone by calcium carbonate precipitation induced by the microbiota inhabiting the stone. Chemosphere 2007, 68, 1929-1936. [CrossRef] [PubMed]

54. Daskalakis, M.I.; Magoulas, A.; Kotoulas, G.; Catsikis, I.; Bakolas, A.; Karageorgis, A.P.; Mavridou, A.; Doulia, D.; Rigas, F. Pseudomonas, Pantoea and Cupriavidus isolates induce calcium carbonate precipitation for biorestoration of ornamental stone. J. Appl. Microbiol. 2013, 115, 409-423. [CrossRef] [PubMed]

55. Perito, B.; Marvasi, M.; Barabesi, C.; Mastromei, G.; Bracci, S.; Vendrell, M.; Tiano, P. A Bacillus subtilis cell fraction $(\mathrm{BCF})$ inducing calcium carbonate precipitation: Biotechnological perspectives for monumental stone reinforcement. J. Cult. Herit. 2014, 15, 345-351. [CrossRef]

56. Jroundi, F.; Schiro, M.; Ruiz-Agudo, E.; Elert, K.; Martin-Sanchez, I.; Gonzalez-Munoz, M.T.; Rodriguez-Navarro, C. Protection and consolidation of stone heritage by self-inoculation with indigenous carbonatogenic bacterial communities. Nat. Commun. 2017, 8, 279. [CrossRef] [PubMed]

57. Ranalli, G.; Sorlini, C. Bioremediation. In Plant Biology for Cultural Heritage. Bioremediation and Conservation; Caneva, G., Nugari, M.P., Salvadori, O., Eds.; The Getty Conservation Institute: Los Angeles, CA, USA, 2008; pp. 340-346.

58. Gauri, K.L.; Parks, L.; Jaynes, J.; Atlas, R. Removal of Sulfated-Crust from Marble Using Sulfate-Reducing Bacteria. In Proceedings of the International Conference on Stone Cleaning and the Nature, Soiling and Decay Mechanisms of Stone, Edinburgh, UK, 14-16 April 1992; pp. 160-165.

59. Atlas, R.M.; Chowdhury, A.N.; Gauri, K.L. Microbial calcification of gypsum-rock and sulfated marble. J. Stud. Conserv. 1988, 33, 149-153.

60. Bosch-Roig, P.; Lustrato, G.; Zanardini, E.; Ranalli, G. Biocleaning of Cultural Heritage stone surfaces and frescoes: Which delivery system can be the most appropriate? Ann. Microbiol. 2015, 65, 1227-1241. [CrossRef]

61. Ranalli, G.; Chiavarini, M.; Guidetti, V.; Marsala, F.; Matteini, M.; Zanardini, E.; Sorlini, C. The use of microorganisms for the removal of sulphates on artistic stoneworks. Int. Biodeterior. Biodegrad. 1997, 40, 255-261. [CrossRef]

62. Cappitelli, F.; Zanardini, E.; Ranalli, G.; Mello, E.; Daffonchio, D.; Sorlini, C. Improved methodology for bioremoval of black crusts on historical stone artworks by use of sulfate-reducing bacteria. Appl. Environ. Microbiol. 2006, 72, 3733-3737. [CrossRef]

63. Cappitelli, F.; Toniolo, L.; Sansonetti, A.; Gulotta, D.; Ranalli, G.; Zanardini, E.; Sorlini, C. Advantages of using microbial technology over traditional chemical technology in removal of black crusts from stone surfaces of historical monuments. Appl. Environ. Microbiol. 2007, 73, 5671-5675. [CrossRef] [PubMed]

64. Polo, A.; Cappitelli, F.; Brusetti, L.; Principi, P.; Villa, F.; Giacomucci, L.; Ranalli, G.; Sorlini, C. Feasibility of removing surface deposits on stone using biological and chemical remediation methods. Microb. Ecol. 2010, 60,1-14. [CrossRef] [PubMed]

65. Cappitelli, F.; Zanardini, E.; Toniolo, L.; Abbruscato, P.; Ranalli, G.; Sorlini, C. Bioconservation of the marble base of the Pietà Rondanini by Michelangelo Buonarroti. J. Appl. Microbiol. 2005, 7, 06675. 
66. Gioventù, E.; Lorenzi, P. Bio-removal of black Crust from marble surface: Comparison with traditional methodologies and application on a sculpture from the Florence's English Cemetery. Procedia Chem. 2013, 8 , 123-129. [CrossRef]

67. Elhagrassy, A.F.; Hakeem, A. Comparative study of biological cleaning and laser techniques for conservation of weathered stone in Failaka Island, Kuwait. Sci. Cult. 2018, 4, 43-50.

68. Doehne, E.F.; Price, C.A. Stone Conservation: An Overview of Current Research; The Getty Conservation Institute: Los Angeles, CA, USA, 2010.

69. Ranalli, G.; Chiavarini, M.; Guidetti, V.; Marsala, F.; Matteini, M.; Zanardini, E.; Sorlini, C. The use of microorganisms for the removal of nitrates and organic substances on artistic stoneworks. In Proceedings of the 8th International Congress on Deterioration and Conservation of Stone, Berlin, Germany, 30 September-4 October 1996.

70. May, E.; Webster, A.M.; Inkpen, R.; Zamarreno, D.; Kuever, J.; Rudolph, C.; Warscheid, T.; Sorlini, C.; Cappitelli, F.; Zanardini, E.; et al. The Biobrush Project for Bioremediation of Heritage Stone. In Heritage Microbiology and Science: Microbes, Monuments and Maritime Materials; May, E., Jones, M., Mitchell, J., Eds.; RSC Publishing: Cambridge, UK, 2008; pp. 76-93.

71. Bosch-Roig, P.; Regidor-Ros, J.L.; Montes-Estellés, R. Biocleaning of nitrate alterations on wall paintings by Pseudomonas stutzeri. Int. Biodeterior. Biodegrad. 2013, 84, 266-274. [CrossRef]

72. Romano, I.; Abbate, M.; Poli, A.; D'Orazio, L. Bio-cleaning of nitrate salt efflorescence on stone samples using extremophilic bacteria. Sci. Rep. 2019, 9, 1668. [CrossRef] [PubMed]

73. Gioventù, E.; Lorenzi, P.F. Valutazione dell'efficacia nell'utilizzo di microrganismi per la biorimozione delle croste nere dai materiali lapidei ed approfondimento delle metodologie applicative. OPD Restauro 2010, 22, 127-138.

74. Troiano, F.; Guiotta, D.; Balloi, A.; Polo, A.; Toniolo, L.; Lombardi, E.; Daffonchio, D.; Sorlini, C.; Cappitelli, F. Successful combination of chemical and biological treatments for the cleaning of stone artworks. Int. Biodeterior. Biodegrad. 2013, 85, 294-304. [CrossRef]

75. Alfano, G.; Lustrato, G.; Belli, C.; Zanardini, E.; Cappitelli, F.; Mello, E.; Sorlini, C.; Ranalli, G. Biodegradation, The bioremoval of nitrate and sulfate alterations on artistic stonework: The case-study of Matera Cathedral after six years from the treatment. Int. Biodeterior. Biodegrad. 2011, 65, 1004-1011. [CrossRef]

76. Mazzoni, M.; Alisi, C.; Tasso, F.; Cecchini, A.; Marconi, P.; Sprocati, A.R. Laponite micro-packs for the selective cleaning of multiple coherent deposits on wall paintings: The case study of Casina Famese on the Palatine Hill (Rome-Italy). Int. Biodeterior. Biodegrad. 2014, 94, 1-11. [CrossRef]

77. Antonioli, P.; Zapparoli, G.; Abbruscato, P.; Sorlini, C.; Ranalli, G.; Righetti, P.G. Art-loving bugs: The resurrection of Spinello Aretino from Pisa's cemetery. Proteomics 2005, 5, 2453-2459. [CrossRef]

78. Ranalli, G.; Belli, C.; Baracchini, C.; Caponi, G.; Pacini, P.; Zanardini, E.; Sorlini, C. Deterioration and bioremediation of frescoes: A case-study. In Molecular Biology and Cultural Heritage; Saiz-Jimenez, C., Ed.; Balkema Publishers: Lisse, The Netherlands, 2003; pp. 243-246.

79. Lustrato, G.; Alfano, G.; Andreotti, A.; Colombini, M.P.; Ranalli, G. Fast biocleaning of mediaeval frescoes using viable bacterial cells. Int. Biodeterior. Biodegrad. 2012, 69, 51-61. [CrossRef]

80. Bosch-Roig, P.; Regidor-Ros, J.L.; Soriano-Sancho, P.; Montes-Estelles, R.M. Biocleaning of animal glue on wall paintings by Pseudomonas stutzeri. Chim. Oggi-Chem. Today 2013, 31, 50-53.

81. Ranalli, G.; Zanardini, E.; Andreotti, A.; Colombini, M.P.; Corti, C.; Bosch-Roig, P.; De Nuntiis, P.; Lustrato, G.; Mandrioli, P.; Rampazzi, L.; et al. Hi-tech restoration by two-steps biocleaning process of Triumph of Death fresco at the Camposanto Monumental Cemetery (Pisa, Italy). J. Appl. Microbiol. 2018, 125, 800-812. [CrossRef] [PubMed]

82. Giacomucci, L.; Toja, F.; Sanmartín, P.; Toniolo, L.; Prieto, B.; Villa, F.; Cappitelli, F. Degradation of nitrocellulose-based paint by Ddesulfuricans ATCC 13541. Biodegradation 2012, 23, 705-716. [CrossRef] [PubMed]

83. Sanmartín, P.; DeAraujo, A.; Vasanthakumar, A.; Mitchell, R. Feasibility study involving the search for natural strains of microorganisms capable of degrading graffiti from heritage materials. Int. Biodeterior. Biodegrad. 2015, 103, 186-190. [CrossRef]

84. Sanmartín, P.; Bosch-Roig, P. Biocleaning to Remove Graffiti: A Real Possibility? Advances towards a Complete Protocol of Action. Coatings 2019, 9, 104. [CrossRef] 
85. Ramirez, J.L.; Santana, M.A.; Galindo-Castro, I.; Gonzalez, A. The role of biotechnology in art preservation. Trends Biotechnol. 2005, 23, 584-588. [CrossRef]

86. Szewczyk, B.; Hoyos-Carvajal, L.; Paluszek, M.; Skrzecz, W.; de Souza, M.L. Baculoviruses-re-emerging biopesticides. Biotechnol. Adv. 2006, 24, 143-160. [CrossRef]

87. Seiber, J.N.; Coats, J.; Duke, S.O.; Gross, A.D. Biopesticides: State of the Art and Future Opportunities. J. Agric. Food Chem. 2014, 62, 11613-11619. [CrossRef]

88. Mikkola, R.; Andersson, M.A.; Grigoriev, P.; Teplova, V.V.; Saris, N.E.; Rainey, F.A.; Salkinoja-Salonen, M.S. Bacillus amyloliquefaciens strains isolated from moisture-damaged buildings produced surfactin and a substance toxic to mammalian cells. Arch. Microbiol. 2004, 181, 314-323.

89. Ben Slimene, I.; Tabbene, O.; Djebali, N.; Cosette, P.; Schmitter, J.M.; Jouenne, T.; Urdaci, M.C.; Limam, F. Putative use of a Bacillus subtilis L194 strain for biocontrol of Phoma medicaginis in Medicago truncatula seedlings. Res. Microbiol. 2012, 163, 388-397. [CrossRef] [PubMed]

90. Caldeira, A.T.; Feio, S.S.; Arteiro, J.M.S.; Roseiro, J.C. Bacillus amyloliquefaciens CCMI 1051 in vitro activity against wood contaminant fungi. Ann. Microbiol. 2007, 57, 29-33. [CrossRef]

91. Tsuge, K.; Akiyama, T.; Shoda, M. Cloning, sequencing, and characterization of the iturin A operon. J. Bacteriol. 2001, 183, 6265-6273. [CrossRef] [PubMed]

92. Silva, M.; Rosado, T.; Teixeira, D.; Candeias, A.; Caldeira, A.T. Production of Green Biocides for Cultural Heritage. Novel Biotechnological Solutions. Int. J. Conserv. Sci. 2015, 6, 519-530.

93. Silva, M.; Pereira, A.; Teixeira, D.; Candeias, A.; Caldeira, A.T. Combined Use of NMR, LC-ESI-MS and Antifungal Tests for Rapid Detection of Bioactive Lipopeptides Produced by Bacillus. Adv. Microbiol. 2016, 6, 788-796. [CrossRef]

94. Silva, M.; Rosado, T.; Teixeira, D.; Candeias, A.; Caldeira, A.T. Green mitigation strategy for cultural heritage: Bacterial potential for biocide production. Environ. Sci. Pollut. Res. Int. 2017, 24, 4871-4881. [CrossRef] [PubMed]

95. Sasso, S.; Scrano, L.; Ventrella, E.; Bonomo, M.G.; Crescenzi, A.; Salzano, G.; Bufo, S.A. Natural biocides to prevent the microbial growth on cultural heritage. In Proceedings of the Conference Built Heritage 2013 Monitoring Conservation Management, Milan, Italy, 18-20 November 2013; pp. 1035-1042.

96. Scrano, L.; Milella, G.; Napolitano, G.; Milan, S.; Lelario, F.; Bonomo, M.G.; Bufo, S.A. Utilizzo virtuoso di biocidi naturali nella conservazione dei manufatti d'interesse storico-culturale. In Proceedings of the XXXII ${ }^{\circ}$ Convegno Nazionale della Società Italiana di Chimica Agraria, Libera Università di Bolzano, Bolzano, Italy, 7-9 September 2014.

97. Elshafie, H.S.; Camele, I.; Racioppi, R.; Scrano, L.; Iacobellis, N.S.; Bufo, S.A. In vitro antifungal activity of Burkholderia gladioli pv. agaricicola against some phytopathogenic fungi. Int. J. Mol. Sci. 2012, 13, 16291-16302. [CrossRef]

98. Marin, E.; Vaccaro, C.; Leis, M. Biotechnology Applied to Historic Stoneworks Conservation: Testing the Potential Harmfulness of Two Biological Biocides. Int. J. Conserv. Sci. 2016, 7, 227-238.

99. Goel, A.K. Anthrax: A disease of biowarfare and public health importance. World J. Clin. Cases 2015, 3, $20-33$. [CrossRef]

100. Granum, P.E.; Lund, T. Bacillus cereus and its food poisoning toxins. FEMS Microbiol. Lett. 1997, 157, $223-228$. [CrossRef]

101. Piewngam, P.; Zheng, Y.; Nguyen, T.H.; Dickey, S.W.; Joo, H.S.; Villaruz, A.E.; Glose, K.A.; Fisher, E.L.; Hunt, R.L.; Li, B.; et al. Pathogen elimination by probiotic Bacillus via signalling interference. Nature 2018, 562, 532-537. [CrossRef] [PubMed]

102. Pinchuk, I.V.; Bressollier, P.; Verneuil, B.; Fenet, B.; Sorokulova, I.B.; Megraud, F.; Urdaci, M.C. In vitro anti-Helicobacter pylori activity of the probiotic strain Bacillus subtilis 3 is due to secretion of antibiotics. Antimicrob. Agents Chemother. 2001, 45, 3156-3161. [CrossRef] [PubMed]

103. Sorokulova, I.B.; Kirik, D.L.; Pinchuk, I.I. Probiotics against Campylobacter Pathogens. J. Travel Med. 1997, 4, 167-170. [CrossRef] [PubMed]

104. Leyva Salas, M.; Mounier, J.; Valence, F.; Coton, M.; Thierry, A.; Coton, E. Antifungal Microbial Agents for Food Biopreservation-A Review. Microorganisms 2017, 5, 37. [CrossRef] [PubMed]

105. Vaseeharan, B.; Ramasamy, P. Control of pathogenic Vibrio spp. by Bacillus subtilis BT23, a possible probiotic treatment for black tiger shrimp Penaeus monodon. Lett. Appl Microbiol. 2003, 36, 83-87. [CrossRef]

106. Cutting, S.M. Bacillus probiotics. Food Microbiol. 2011, 28, 214-220. [CrossRef] [PubMed] 
107. Mingmongkolchai, S.; Panbangred, W. Bacillus probiotics: An alternative to antibiotics for livestock production. J. Appl. Microbiol. 2018, 124, 1334-1346. [CrossRef]

108. Xu, S.; Lin, Y.; Zeng, D.; Zhou, M.; Zeng, Y.; Wang, H.; Zhou, Y.; Zhu, H.; Pan, K.; Jing, B.; et al. Bacillus licheniformis normalize the ileum microbiota of chickens infected with necrotic enteritis. Sci. Rep. 2018, 8, 1744. [CrossRef]

109. Mazzacane, S.; Finzi, G.; Aparo, L.; Balboni, P.G.; Vandini, A.; Lanzoni, L.; Camerada, M.T.; Coccagna, M.; Antonioli, P.; Branchini, A.; et al. The Sanitation of Hospital Stays: New Strategies for The Reduction of HAIs. Health Manag. 2014, 14, 1-12.

110. Vandini, A.; Temmerman, R.; Frabetti, A.; Caselli, E.; Antonioli, P.; Balboni, P.G.; Platano, D.; Branchini, A.; Mazzacane, S. Hard Surface Biocontrol in Hospitals Using Microbial-Based Cleaning Products. PLoS ONE 2014, 9, e108598. [CrossRef]

111. Caselli, E.; D'Accolti, M.; Vandini, A.; Lanzoni, L.; Camerada, M.T.; Coccagna, M.; Branchini, A.; Antonioli, P.; Balboni, P.G.; Di Luca, D.; et al. Impact of a Probiotic-Based Cleaning Intervention on the Microbiota Ecosystem of the Hospital Surfaces: Focus on the Resistome Remodulation. PLoS ONE 2016, 11, e0148857. [CrossRef]

112. Caselli, E.; Antonioli, P.; Mazzacane, S. Safety of probiotics used for hospital environmental sanitation. J. Hosp. Infect. 2016, 94, 193-194. [CrossRef] [PubMed]

113. Caselli, E. Hygiene: Microbial strategies to reduce pathogens and drug resistance in clinical settings. Microb. Biotechnol. 2017, 10, 1079-1083. [CrossRef]

114. Caselli, E.; Brusaferro, S.; Coccagna, M.; Arnoldo, L.; Berloco, F.; Antonioli, P.; Tarricone, R.; Pelissero, G.; Nola, S.; La Fauci, V.; et al. Reducing healthcare-associated infections incidence by a probiotic-based sanitation system: A multicentre, prospective, intervention study. PLoS ONE 2018, 13, e0199616. [CrossRef] [PubMed]

115. Caselli, E.; Arnoldo, L.; Rognoni, C.; D’Accolti, M.; Soffritti, I.; Lanzoni, L.; Bisi, M.; Volta, A.; Tarricone, R.; Brusaferro, S.; et al. Impact of a probiotic-based hospital sanitation on antimicrobial resistance and HAI-associated antimicrobial consumption and costs: A multicenter study. Infect. Drug Resist. 2019, 12, 501-510. [CrossRef]

116. Perito, B.; Cavalieri, D. Innovative metagenomic approaches for detection of microbial communities involved in biodeterioration of cultural heritage. In IOP Conference Series: Materials Science and Engineering; IOP Publishing: Bristol, UK, 2018; p. 012074. 